\title{
Towards a human economy: reflections on a new project
}

\author{
John Sharp \\ Department of Anthropology and Archaeology, University of Pretoria, Private Bag X20, Hatfield, Pretoria, 0028, South Africa \\ john.sharp@up.ac.za
}

The University of Pretoria's Human Economy project began at the end of 2010. To date it has involved eighteen post-doctoral fellows, drawn from around the world, and eight doctoral candidates, all from Africa. This paper reviews the project's progress, drawing attention to how its participants have come to construe the notion of a 'human economy' and the main social theorists on whom they have drawn in doing so. The development of our thinking regarding a human economy is explained by reference to the two edited volumes, comprising contributions from all the post-doctoral fellows, which will be published in the near future. Challenges for future research are considered in the final part of the paper.

Keywords: Human economy, plural economy, Mauss, Polanyi, market exchange, mutuality, reform, revolution

\section{Parallels}

Keith Hart and I had the idea for a research project under the name 'The Human Economy' late in 2010, and we took in a first cohort of post-doctoral fellows at the University of Pretoria at the start of $20 \mathrm{II}$. Yet I want to start my reflections on this project by referring briefly to an earlier project in which I was involved at the University of Cape Town. Because I saw several parallels between the two, the success of the 'South African Keywords' project made me jump at the prospect of participating in the Human Economy project.

One parallel has to do with timing. The Keywords project rested on the straightforward premise that the terms used in apartheid thinking comprised a representation, rather than a simple description, of South African society. The book that emerged from the project (Boonzaier and Sharp 1988) was widely read by diverse audiences. One comprised apartheid's supporters - both active and passive - who had begun to realise that the then South African status quo was unsustainable. The project's timing was therefore of considerable significance - years of open resistance, among other things to the tri-cameral parliament of the early 1980s, had produced this new awareness. Civil disobedience in city streets throughout this decade had a direct impact on white South Africans that distant suffering in the Bantustans had not. But those who had benefited from apartheid were so steeped in its logic and convinced of its 'naturalness' that they could not put their finger on the logic's flaws. By pointing out the representational character of apartheid discourse at a crucial time, the South African Keywords volume helped them to do this.

The starting point for a project looking towards a human economy has surely to be similar. It must start from the premise that the language used over the past 40 years to proselytise the ostensible virtues of a globalising free market is a representation rather than a description of the real economy of people's everyday lives. It is, moreover, an interested representation, one that serves the interests of one section of the world's population rather than those of others. While any attempt to map out a path to a human economy should have wide appeal, I think there is reason to believe that many people within the ranks of the beneficiaries of the global free market system may now have become more open to the project's argument than they would have been a decade or two ago.

One reason is to be found in the 2008 global financial crisis and the subsequent sovereign debt crises. For the first time since the 1970s the destruction that an unregulated market can cause has been felt not just in distant parts of the 'undeveloped' world but in the system's principal citadels. Many millions of people in North America and Europe had benefited from the cheap credit boom of the 1990s, and were given to faith in the notion that the end of the Cold War had ushered in a new phase in the evolution of capitalism in which the market would spread its benign largesse to all corners of the world once it had been freed from political interference. They now had a rude awakening. Like their white South African counterparts during apartheid's endgame, such people may now be open to input from social scientists which shows that since free-market ideology is not a simple description of the global economy there may well be other ways in which to organise economic life.

Of course, a project under a Human Economy umbrella has a broader scope than South Africa alone, and more elaborate ambitions than the Keywords project had. But a base in southern Africa for a project along these lines is important, given that scholars in the region, and indeed the continent, have not yet played a part in the critique of neo-liberalism comparable to their prominent role in the earlier critique of colonialism. For this reason we have recruited all our Human Economy doctoral candidates from Africa, and have linked them up with post-doctoral fellows from around the world, anticipating that the resulting interaction and mentoring will soon put young African scholars in a position to make their particular voice heard on socio-politically relevant issues.

\section{Plural economy}

If the Keywords project was able to derive inspiration from the then-relatively new field of discourse analysis, the Pretoria Human Economy project is fortunate to be able to draw on the book The Human Economy: a citizen's guide (Hart et al. 2010), published just as the project started. The book is important because of its aim to bring several trends in economic theory and practice that had flourished in South Amer- 
ica, France and Scandinavia to the attention of an Anglophone world so enamoured of neo-liberal discourse that they had hitherto been ignored. The book's point of departure was that it is necessary to look beyond the twin poles of much $20^{\text {th }}$ century debate about the economy, pointing out the limitations of any knee-jerk response to the early $21^{\text {st }}$ century crisis of the free market that advocated a swing of the pendulum towards distribution by means of bureaucratic command. As the editors of The Human Economy argued in their introduction, $20^{\text {th }}$ century history showed that

Market society sustained by concern for individual freedom generated huge inequalities; the submission of the economy to political will on the pretext of equality led to suppression of freedom. These two solutions called democracy itself into question, whether in the form of totalitarian systems or, with similar result, through the subordination of political power to that of money (Hart et al. 2010:9).

Moreover, the contributors to the book insisted, the real economies of the $20^{\text {th }}$ century were always much more alike than the abstract models by which they were represented. The United States economy may have been held up as the embodiment of capitalism, but its enormous defence industry, under the Pentagon's direction, was scarcely conducted according to a free-market principle. Large parts of all economies were therefore hidden by the abstract models used to contrast them.

Contributors to the 2010 Human Economy volume set out to describe these hidden parts and to assess their potential to point to alternatives to the abstract models of capitalism and socialism. Their focus in this endeavour was on the initiatives taken by ordinary people to insert themselves into the current, unequal world economy in the course of their everyday efforts in order to fashion a livelihood. Some of these efforts were organised according to market principles, but others bore witness to people's ready participation in activities based on solidarity and mutuality. These activities were discussed under headings such as 'third sector', 'solidarity economy', 'local development', and 'social enterprise', and the emphasis was invariably on how this kind of initiative was part and parcel of a plural economy in which social movements aimed at mutuality existed alongside, and in many instances intertwined with, market-oriented institutions.

The University of Pretoria's first cohort of Human Economy post-doctoral fellows was obliged to draw on its members' prior anthropological, sociological or historical research, which had not necessarily focused on exploring forms of local economic organisation such as co-operatives, work-creation initiatives, and community service delivery projects. But this limitation was diminished by encouraging the fellows to reflect closely on how, and to what extent, the subjects of their doctoral studies had managed to reconcile the principles of freedom and equality, self-reliance and social belonging, and self-interest and mutuality in whatever livelihood-generating activities they had undertaken. The fact that the first group of fellows had done their doctoral research in contexts such as South Africa, Zimbabwe and Mozambique, Brazil and
Cape Verde, and Nepal provided ample scope for comparative analysis, discussed further below.

\section{Theoretical direction}

The principal guiding theorists for such an exercise are unquestionably Marcel Mauss and Karl Polanyi. Mauss was deeply cognisant of the fact that human behaviour in all societies is guided by a complex range of principles and motives, sometimes partially contradictory. In this regard his essay on The Gift (Mauss 1925) has often been misread, as if he had been contrasting gift economies with market ones and arranging them in a sequence of social evolution (Hart 2007). But he was actually saying that both forms combine self-interest and mutuality, although in different ways, and that this combination was hidden, in his day as in ours, by the ideology of the free market. Mauss' insistence that all possibilities are always present in exchange relationships between humans has recently been reiterated, in a characteristically ebullient exposition, by Graeber (201 I:89-126), who seems, at least in this instance, not to disagree with Mauss' proposition that all these possibilities should be given room to express themselves in a plural economy.

Mauss' (1997) comment, in his political writings, on Lenin's attempt to abolish the market for agricultural produce in the Soviet Union in the early 1920s is informative in this regard. Although he was deeply committed to socialist ideals, Mauss believed that sole reliance on distribution by state bureaucracy would abstract one aspect - people's capacity to act altruistically - from the complexity of their actual behaviour. Moreover, this process of elevation would simplify social reality and turn the abstraction into an iron cage that stifled people's ability to reconcile self-interest and mutuality. Acting in the name of equality to submit the economy entirely to political will - even the will of a party representing itself as the vanguard of the proletariat - would lead, he warned, to 'the suppression of freedom'.

Polanyi (1944) concentrated on analysing the consequences of the emergence of the philosophy of economic liberalism and the near-emergence of a self-regulating market in $19^{\text {th }}$ century Europe. The philosophy championed the 'naturalness' of the propensity to truck and barter, but Polanyi showed, in a manner similar to Mauss, that this involved elevating one dimension of human behaviour above the rest. $\mathrm{He}$ argued that a fully self-regulating economy was impossible to attain and would, in any event, be entirely unlivable. But even the degree to which it had been realised in the $19^{\text {th }}$ century, by the violent transformation of land, labour and money into 'fictitious' commodities, had been sufficient to provoke various counter-movements for the 'self-protection' of society. Some of these, such as fascism, had proved extremely dangerous, not least because the fact that they had elevated the subjection of self to society above all idea of freedom, with disastrous results, had strengthened the hand of those holding to the 'moral illusion of freedom' characteristic of economic liberalism - a freedom that came at the cost of justice and security. Polanyi was convinced that there was a way out of this dilemma, but only if it was possible to fashion a combination of state, market, and power that was more open to human interests than those inspired by abstract philosophical models had been. He saw the exercise of power and compul- 
sion by the state as an inescapable part of any complex, industrial society. At the same time, 'the end of market society means in no way the absence of markets'.

(Markets) will continue, in various fashions, to ensure the freedom of the consumer, to indicate the shifting of demand, to influence producers' income, and to serve as an instrument of accountancy, while ceasing to be an organ of economic self-regulation (Polanyi 1944:252).

This passage comes right at the end of The Great Transformation, and Polanyi offered little more by way of a vision of what post-'market society' might look like. But the reticence was studied, in keeping with his approach (and also Mauss' approach) to the issues under discussion. If one starts - as they both did - by holding that people's behaviour displays a complex of self-interest and mutuality which they show evidence of knowing, for the most part, how to deploy sensibly according to changing everyday circumstance, then it is wise to give them as much leeway as possible to fashion their own futures. The compulsion Polanyi recognised as being necessary in any complex society was to be exercised by a democratic state, and would be of much the same order as the spontaneous compulsion imposed by bonds of mutuality when people were obliged to take the complexity of their relationships with others into account in their daily lives. I think that the argument of The Gift is, in many respects, Mauss' statement of faith in ordinary people's good sense and judgement, from which they are usually diverted only by the exercise of violence in the name of one or other abstract vision of society.

\section{What has been achieved to date?}

The Pretoria project has recruited a total of 18 postdoctoral fellows to date, divided into 20I I-2 and 20I2-3 cohorts (the second supplemented by fellows who arrived at the start of 2013). Each cohort has collaborated to produce a volume based on its members' prior researches, and both volumes will be published in 2014. My aim here is not to give the content of the books away in any detail, but rather to indicate the development of our collective ideas over the past two-and-ahalf years.

As mentioned above, the first group of fellows was constrained by the need to think their way into what we have come to call a human economy approach and to adapt their already-completed doctoral research to this approach. Neither Keith Hart nor I attempted any ex-cathedra pronouncement at the outset about what such a human economy approach should entail, and the notion that the works of Mauss and Polanyi are central to (although by no means the only sources for) this approach is the outcome of collective exploration.

For these reasons a good portion of the first volume, on People, Money and Power in the Economic Crisis, is devoted to exploring the obstacles confronting attempts by people in various parts of the South to insert themselves into the current, highly unequal global economy. Much is written about, for instance, the difficulties faced by street traders in Zimbabwe, migrants to South Africa from the Democratic Republic of Congo, inhabitants of the former homeland of Venda, white workers subjected to de-industrialisation and the end of apartheid in Pretoria, and young black men in Soweto who are in employment that is at best insecure. This aspect of the book is not, of course, especially new, given that revelations of the manner in which 'neo-liberal globalisation' has hamstrung people in diverse parts of the so-called developing world has been a stock-in-trade of humanities disciplines such as sociology, anthropology, and history for some time.

There is, however, a new dimension to our first volume's treatment of a well-established theme. This is that we try to go beyond regarding neo-liberalism as a mysterious force one that neither we nor the subjects of our research are able to explain - which is simply engulfing the world and bringing misery to most of its inhabitants. More than a few recent studies approach neo-liberalism in this fashion - as if it were a witch - and give little insight into whether the label refers to an ideological prescription about how the global market ought to behave or the actual behaviour of the market. We take the view that neo-liberalism denotes an ideology to which those exercising power over the lives of ordinary people may or may not subscribe or may subscribe in a partial way.

From this perspective we endeavour to show that the specific obstacles to economic participation confronting ordinary people in different parts of the global South turn on the highly variable character of the relationship between those with power in the form of money and those with political power (granting that these categories may, in many instances, overlap). The South African state appears to have been in thrall to the demands of capital since the late 1990s, and there is as yet small evidence that it is becoming more assertive. Moreover the capitalists' demands in this context are for deregulation, allowing them to do whatever they like, rather than for the establishment of a free market, which would, of course, constrain them. This relationship between those with power in the form of money and the ruling elite imposes particular characteristics on the challenges to economic participation faced by millions of South Africans, and these characteristics are not necessarily to be found in Zimbabwe or Mozambique, where those with political power have had no significant capitalists from whom to take direction, or the DRC, where the state is so weak that the mining industry is able to establish enclave economies sealed off from society. And one can contrast all these African countries with Lula's Brazil, where a seemingly benign state-capital relationship created conditions in which economic participation increased and began, indeed, to become democratic.

Many of the contributions in the first volume in our series also looked beyond the cataloguing of constraints in order to explore the initiatives ordinary people took to deal with them. The chapter on Soweto (Krige forthcoming) is exemplary in this regard, since it details the efforts by a group of young men there to update well-established forms of mutual assistance such as informal savings clubs by inserting them into the sphere of higher finance, investing their pooled resources in commercial banks, and possibly in due course on the stock exchange, in order to extend the time-honoured notion of working for one's money by obliging their money to work for their collective good. Krige's account of their crea- 
tive response to the financialisation of the higher reaches of the economy means that they have been able to bend the process of financialisation to their local designs, at least to some extent, rather than experience the process as a demonic force laying waste to their aspirations.

The second volume by the 20I2-3 post-doctoral fellows expands this focus on what people do to insert themselves into an unequal global economy. These fellows had the advantage of a clearer idea of what they were letting themselves in for by signing up for the Pretoria Human Economy project, and we were better able to select participants who had already done research that would extend this theme. Thus Economy for and against Democracy explores several instances of popular initiatives to sustain and enhance economic participation in the face of severe obstacles, instances that have at least the potential to shape the economy in the direction of greater democracy. One case details the attempts by people in Athens to devise means for direct exchange between producers and consumers, particularly of agricultural goods, which exclude all middlemen (Rakopoulos forthcoming). These efforts are, in one sense, a response to the immediacy of the sovereign debt crisis, which has led to decreasing employment, lower wages and higher prices in Greece. But close attention to the manner in which the activists involved explain what they have set out to achieve, and communicate their intentions to people they want to recruit to the cause, may provide insight into prospects for longer-term transformation of the current economic order. The same is true of a second contribution, based on detailed ethnographic study in a working class district of Buenos Aires, which poses the explicit challenge of what could be done - and by whom - to ensure that the extension of micro-finance actually works for rather than against the interests of indigent Argentines (Saiag forthcoming).

The Pretoria Human Economy project is therefore steadily embracing the notion that its concerns must extend to an active approach to the issue of forging greater economic democracy. In this vein, one of the contributions to the second volume considers the prospects for initiating a social movement for a human economy, using the success of the international feminist movement as an example of what can be achieved (Sutton-Brown forthcoming). This is entirely in line with the intentions of the contributors to the original, 2010 Human Economy volume.

\section{Future directions}

Our vision of a human economy could easily be misconstrued as being reformist rather than revolutionary. Our starting point is that the economy is made and remade by the activities of ordinary people in their daily lives, but that their achievements in this regard have been obscured, particularly since the early 1970s, by a utopian ideology that renders the economy an impersonal sphere of activity remote from ordinary people. Finding a way to reinstate the significance of their concerns is a first step towards the desired end.

At the same time, however, a human economy cannot be entirely made up of people's local, everyday concerns, unless humanity is willing to contemplate a return to a condition mythical, of course - of small-scale autarky. As Mauss and Polanyi recognised, markets and money have long worked to extend people's concerns beyond the quotidian and the local, and to link them to distant others via relationships that are both personal and impersonal. Bureaucracy has also been a key means by which people have, historically, been able to reach out to others beyond the local and the everyday, and when it works well, which means impersonally and efficiently - it has been a key to the satisfaction of personal needs and ambitions. A human economy is not, at least in our view, an economy bereft of markets, money, and bureaucracy. Nor can one ignore the fact that markets and money, and other technologies of communication, have developed to the point where they now span the globe in ways that have created a single world-society. Is all of this to be dismissed as the source of our economic woes, or does it offer new possibilities for countering them, providing we are willing to work, at least at first, in the cracks and interstices of institutions and technologies that are currently deployed to most of humanity's disadvantage? We are all now aware that the US government can scan the internet, but we should not forget that this technology also makes Wiki-leaks possible.

Our premise is that a human economy is already all around us, but is currently hidden from view. Graeber's discussion of the moral bases of exchange in all societies suggests that he may not disagree with this proposition. On the other hand, however, the rest of his book on Debt (Graeber 20II) argues that human economies were found in a stage of history which has passed. They were economies "concerned not with the accumulation of things, but with the creation, destruction, and re-arranging of human beings" (Graeber 201 I:130), in the fashion of the 'traditional' African societies of the classic ethnographies. In so far as money was used in such economies it was in the form of 'social currencies' that restricted the convertibility of people and things. Graeber is careful to say that human economies were not necessarily humane, since the re-arranging of people could be and often was a violent process. But those human economies of the past were destroyed by the exercise of much greater violence by representatives of larger civilisations. Exposure to the violence of the slave trade, for instance, undermined the principle on which the human economies that re-arranged people were based, and did so well beyond their capacity to resist.

This argument implies that a return to an economy focused on people - or the creation of a new, possibly more humane one - would require a radical break with the present complex of markets, money and states, all of which work by making thin abstractions of real people. Such a view is certainly in line with the political views Graeber (2004) has expressed elsewhere, but one still awaits his full exposition of what conditions would trigger such a break and how people should act to take advantage of them.

One can readily foresee a future volume in our Human Economy series taking up these issues with Graeber (among others), preferably by persuading him to engage directly in the conversation. Are the recent economic crises that have beset the global North sufficient to bring down the capitalist edifice soon (bearing in mind that large parts of the global South - notably Africa - have struggled with a sovereign debt crisis for forty years with little result beyond the impoverishment of their inhabitants)? And do the Occupy movements 
(and the Arab Spring movements) point the way ahead for political action to fashion a new human economy?

In his recent Manifesto for a Human Economy, Hart (2013) insisted that public communication and information were crucial dimensions of our project. Ordinary people understand their own circumstances well enough, he argued, and would know how to manoeuvre between self-interest and mutuality in dealing with them if there were no obstacles in their path. But they often do not know what the obstacles are, why they are there, and how best to avoid them. In other words a Human Economy project cannot retreat into the comfortable illusion that 'the people' know best and all the intellectuals have to do is to listen to them. Listening to them is important, of course, and our project is premised on the conviction that anthropologists - and others in humanities disciplines - are equipped to make a better job of this than economists have done. But can we also be more successful in telling them what they do not, and cannot otherwise, know?

\section{Parallels}

With hindsight I think that one of the reasons the South African Keywords project was successful was that - in addition to its timing - its contributors managed to avoid the temptation to hector any of its audiences, including the beneficiaries of apartheid. We explained, on the contrary, that many of the constructions placed on the terms used in the 'discourse of (white) domination' in South Africa had their counterparts, if not their origins, in the history of our own discipline. It was our familiarity with this controversial history that afforded us the means, and the authority, to make critical comment on the discourse.

This is why I am wary of recent work in the social sciences that is stridently critical of economists. Miller (2002), for instance, argued that economists' market models are entirely illusory, because real people's buying and selling behaviour is always more complex than they make out. But if economists inhabit a looking-glass world, they are nonetheless in the grip of a beguiling fantasy. In an earlier work Miller (1998) acknowledged that economists have enough influence to shape real people's behaviour to an approximation of their models, although he continued to insist that the correspondence would never, in the final analysis, be perfect. Callon (1998; 2007), on the other hand, takes the argument to its logical conclusion, asserting that the market model serves to 'format' people's intentions and actions to such an extent that one can legitimately insist that economists (in whose ranks he includes accountants and actuaries) actually manufacture the markets they claim merely to describe. There is no prospect for a human economy if this kind of argument is right.

But I do not think it is, and one wonders, in any event, if it is wise for social scientists to denounce the efforts of economists in such self-assured fashion. It seems more sensible for us to acknowledge that our disciplines have often gone to work in very similar ways. A market in which participants ostensibly act solely to maximise utilitarian returns is certainly an abstraction from which many dangerous, dehumanising implications flow. But how different, in principle, are abstractions such as 'culture' and 'society' when they are assumed to denote an objective reality beyond our model making? The economists' models are undoubtedly more influential, at present, than the abstractions put forward by anthropologists and sociologists, but South African anthropologists, in particular, should be able to recall a time, not so long ago, when the understanding of culture their discipline popularised was put to anything but constructive ends. It is the fact that we have traversed similar analytical terrain that gives us the authority to make our voices heard, not simply against economists (who are by no means all of one mind with regard to received wisdom in their discipline), but in favour of a human economy.

The advent of a human economy, making space for a plurality of economic forms and principles of exchange and association, and leading to greater economic democracy, would amount to a revolutionary break with the past.

\section{References}

Boonzaier, Emile; John Sharp (Eds). 1988. South African keywords: the uses and abuses of political concepts. Cape Town: David Philip.

Callon, Michel (Ed). 1998. The laws of the markets. Oxford: Blackwell Publishers.

Callon, Michel. 2007. 'What does it mean to say that economics is performative?', in Do economists make markets? Edited by D. MacKenzie, F. Muniesa, and L., Pp.3 I I-357. Princeton: Princeton University Press.

Graeber, David. 2004. Fragments of an anarchist anthropology. Chicago: Prickly Paradigm Press.

Graeber, David. 201 I. Debt: the first five thousand years. New York: Melville House.

Hart, Keith. 2007. Marcel Mauss: in pursuit of the whole. Comparative Studies in Society and History 49(2): 473-485.

Hart, Keith. 2013. Manifesto for a human economy. The Memory Bank. Online: http://thememorybank.co.uk/20/3/0I/20/objectmethods-and-principles-of-a-human-economy [Accessed 10 August 2013]

Hart, Keith; Jean-Louis Laville and Antonio Cattani (Eds). 20I0. The human economy: a citizen's guide. Cambridge: Polity Press.

Krige, Detlev. Forthcoming. "'Letting money work for us": selforganisation and financialisation from below in an all-male savings club in Soweto', in People, money and power in the economic crisis. Edited by K. Hart and J. Sharp, The Human Economy Series No. I. Oxford and New York: Berghahn Press.

Mauss, Marcel. 1990 [1925]. The Gift: form and reason of exchange in archaic societies. London: Routledge.

Mauss, Marcel. 1997. Écrits Politiques. M. Fornier (Ed). Paris: Fayard.

Miller, Daniel. 1998. 'A theory of virtualism', in Virtualism: a new political economy. Edited by J, Carrier and D. Miller. Oxford: Berg.

Miller, Daniel. 2002. Turning Callon the right way up. Economy and Society 31:218-233.

Polanyi, Karl. 200I [1944]. The Great Transformation: the political and economic origins of our times. Boston, MA: Beacon Press.

Rakopoulos, Theodoros. Forthcoming. 'Solidarity economy in contemporary Greece: "movimentality", economic democracy and social reproduction', in Economy for and against democracy. Edited by K. Hart and J. Sharp, The Human Economy Series No. 2. Oxford and New York: Berghahn Press.

Saiag, Hadrien. Forthcoming. 'Money for a human economy: a reflection from Argentina', in Economy for and against democracy. Edited by K. Hart and J. Sharp, The Human Economy Series No. 2. Oxford and New York: Berghahn Press.

Sutton-Brown, Camille. Forthcoming. 'Building a human economy movement: the precedent of transnational feminism', in Economy for and against democracy. Edited by K. Hart and J. Sharp, The Human Economy Series No. 2. Oxford and New York: Berghahn Press. 